\title{
Long-term stability of allozyme frequencies in a wood lemming, Myopus schisticolor, population with a biased sex ratio and density fluctuations
}

\author{
JA Vuorinen and O Eskelinen \\ Department of Biology, University of Joensuu, PO Box 111, FIN-80101 Joensuu, Finland
}

\begin{abstract}
Wood lemming (Myopus schisticolor) populations are characterized by female biased sex ratios and cyclic variations in population size. Both of these characteristics are assumed to reduce genetic variation and thus affect the evolutionary adaptation of the species. We addressed these questions by studying the genetic structure of a wood lemming population from eastern Finland by isozyme markers during a 21-year period, which corresponds to 40-50 generations. Contingency tests showed that genotypic proportions conformed to Hardy-Weinberg equilibrium in each of the four sampling years. Among the temporal replicates, allele frequencies differed most by 0.14 and were not significant. Genetic
\end{abstract}

variation was also stable and fairly high with a mean observed heterozygosity of $H=0.057$. Variability in the Heinävesi population was higher than previously reported in wood lemming. The difference was mainly caused by variation at a phosphoglucomutase locus that was monomorphic in earlier studies. Significant linkage disequilibrium was observed in three of the comparisons but the disequilibrium did not appear consistently in all years. This pattern was also evidenced by the variance components, which indicated that selection favoured for specific allele pairs only in few subsamples. Heredity (2005) 94, 443-447. doi:10.1038/sj.hdy.6800639 Published online 19 January 2005

Keywords: Myopus schisticolor; variation; stability; temporal; allozyme; polymorphism

\section{Introduction}

The analyses of genetic population structure and genetic diversity are in most cases based on one-time sampling. The implicit assumption of such sampling is that temporal changes are negligible. However, no finite population is genetically stable over time because of genetic drift. Shifts in gene frequencies are expected particularly in organisms that have small or cyclically fluctuating populations, uneven sex ratios, low migration rates or overlapping generations. The wood lemming, Myopus schisticolor, is a Palearctic mammalian herbivore inhabiting coniferous taiga forests from southern Norway to eastern Siberia (Fedorov et al, 1995). Its populations are universally characterized by female biased sex ratios caused by the presence of two different types of $X$ chromosomes (Fredga et al, 1976). It also has density fluctuations like most other northern microtine rodents. Both of these factors reduce effective population size $N_{\mathrm{e}}$, and allele frequencies may therefore change due to stochastic processes. Additionally, wood lemming populations in the Scandinavian Peninsula may have experienced population bottlenecks and founder effect during colonization events after the last glaciation. Analyses of temporally replicated samples may therefore offer a more thorough and dependable picture of population structure and microevolutionary processes involved.

Correspondence: JA Vuorinen, Department of Biology, University of Joensuu, PO Box 111, FIN-80101 Joensuu, Finland;

E-mail: jukka.vuorinen@joensuu.fi

Received 10 February 2004; accepted 12 November 2004; published online 19 January 2005
The genetic population structure of the wood lemming has been documented earlier from Siberia and Scandinavia both on microgeographic (Fedorov, 1990, 1991) and macrogeographic (Fedorov, 1993; Fredga et al, 1993; Fedorov et al, 1995) scales. In two of these locations, temporal replicates were also examined. In a Norwegian population, allele frequencies did not differ between two consecutive years (Fredga et al, 1993) whereas in a Siberian population significant heterogeneity was observed among four successive years (Fedorov, 1993). Later, Fedorov et al (1995) presented a synthesis of spatial genetic differentiation in wood lemming populations from Fennoscandia to eastern Siberia. Surprisingly, different single-locus patterns of subdivision were observed. At isocitrate dehydrogenase locus, the populations were differentiated both within and between regions, whereas at glucose-6-phosphate isomerase locus differentiation was observed only between regions.

The wood lemming differs from the prevalent mammalian sex determination system because it has two types of $X$ chromosomes, $X$ and $X^{*}$ (Fredga et al, 1976). The variant $X^{*}$ contains a deletion that causes sex reversal of $X^{*} Y$ individuals (Herbst et al, 1978; Liu et al, 1998). Therefore, $X X^{*}$ females produce only $1 / 4$ males. The aberrant $X^{*} Y$ females produce only daughters due to meiotic drive in the foetal ovary (Fredga et al, 1976). As a consequence, the frequency of males and the three female types are the same with the condition that the fitness of all female types are equal (Bengtsson, 1977). The theoretical proportion of males in a wood lemming population is thus $25 \%$, which reduces the effective population size by $25 \%$. Fredga et al (1993) have noted that the sex ratio seems to vary depending on the time of 
the year or on the phase of the population cycle. First it was hypothesized that the female biased sex ratio is maintained by inbreeding, especially when the population density is low (Maynard Smith and Stenseth, 1978; Stenseth, 1978). However, isozyme studies showed that wood lemming populations are generally in HardyWeinberg equilibrium (HWE) (Fedorov, 1990, 1991, 1993; Gileva and Fedorov, 1991; Fredga et al, 1993) indicating random mating.

Cyclic density fluctuations are typical for most northern microtine rodents including true lemmings and the wood lemming (Krebs and Myers, 1974; Stenseth, 1999). In wood lemming populations, the densities are very low during the low phases (Stenseth and Ims, 1993) significantly reducing effective population size $N_{\mathrm{e}}$. During the bottlenecks allele frequencies should fluctuate by random genetic drift causing fixation of alleles and reduction of mean heterozygosity. Previous studies on wood lemming have reported low genetic variation both in isozymes (Fedorov, 1990; Fredga et al, 1993) and in mitochondrial DNA (Fedorov et al, 1996), evidencing the effects of biased sex ratio and bottlenecks.

In this study we describe the genetic population structure of a wood lemming population from eastern Finland over a 21-year period. In the studied Heinävesi population the sex ratio has been around $25 \%$ during late summer and autumn and density fluctuations have been regular with 3-year intervals (Eskelinen, 1997). Our objectives were (1) to determine the amount of genetic variation and its possible temporal fluctuation by allozyme electrophoresis; (2) to detect possible effects of the unusual population sex ratio, population fluctuations and bottlenecks on genetic diversity; (3) and to compare the amount of genetic diversity with previously studied Fennoscandian and Siberian populations to trace the possible population genetic consequences of postglacial re-colonization.

\section{Materials and methods}

A total of 184 adult wood lemmings were collected during four years (1982 $n=27,1996 n=28,1999 n=32$ and $2002 n=97)$ from Heinävesi, eastern Finland. The time span corresponds to approximately 40-50 generations. The collecting years represent major population peaks except in 1999 when only a small peak was seen. The population density was monitored each year between 1982 and 2003 (Eskelinen, 2004), but enough animals were only available during population peaks. Migrating animals were usually collected dead under railway bridges. The 1982-1999 samples originate from three different locations (between Koivumäki and Sepänsalmi) within a distance of 9-14 km. The 2002 sample is from one location (Sappu) and was collected during 57 days in August-October. Further sampling details with a map of the study area are given in Eskelinen (1997). Animals were stored at $-18^{\circ} \mathrm{C}$ or $-40^{\circ} \mathrm{C}$ for a maximum of 6 months before analysis. Genetic variation was studied from allozyme data obtained by horizontal starch gel electrophoresis on crude extracts of muscle and liver tissues. The buffer systems used were (A) TRIScitrate buffer with pH 8.1 (Ridgway et al, 1970), (B) N-(3aminopropyl)-morpholine-citrate buffer with $\mathrm{pH} 6.1$ (Clayton and Tretiak, 1972), and (S) TRIS-citrate buffer with pH 7.1 (Shaw and Prasad, 1970). The following 13 enzymes representing 20 enzyme coding loci were assayed using methods that are in general use: alcohol dehydrogenase (ADH, EC 1.1.1.1; Adh), aspartate transaminase (AST, EC 2.6.1.1; Ast-1, Ast-2), creatine kinase (CK, EC 2.7.3.2; Ck-1, Ck-2), glucose-6-phosphate isomerase (GPI, EC 5.3.1.9; Gpi), glycerol-3-phosphate dehydrogenase (NAD) (G3PDH, EC 1.1.1.8; G3pdh), L-iditol 2-dehydrogenase (IDDH, EC 1.1.1.14; Iddh), isocitrate dehydrogenase (NADP) (IDHP, EC 1.1.1.42; Idhp-1, Idhp2), L-lactate dehydrogenease (LDH, EC 1.1.1.27; $L d h-1$, $L d h-2)$, malate dehydrogenase (MDH, EC 1.1.1.37; Mdh-1, $M d h-2)$, malate dehydrogenase (oxaloacetate-decarboxylating) (NADP) (MEP, EC 1.1.1.40; Мep-1, Мep-2), phosphoglucomutase (PGM, EC 5.4.2.2; Pgm), phosphogluconate dehydrogenase (decarboxylating) (PGDH, EC 1.1.1.44; $P g d h$ ), superoxide dismutase (SOD, EC 1.15.1.1; Sod-1, Sod-2). Liver tissue and buffer system B were used routinely with the following exceptions: for ADH buffer $A$ was used and for CK, IDDH and LDH buffers S or A were used. During the pilot phase, some additional enzymes were stained. Two of them, namely esterase (EC 3.1.1. - using $\alpha$-napthyl acetate as the substrate) and aminopeptidase (EC 3.4.11. - stained with the LAP recipe of Shaw and Prasad (1970)) were variable, but inadequate resolution prevented their use as markers. Enzyme names and numbers follow Enzyme Nomenclature (1992).

Allele frequencies and observed heterozygosities were calculated from genetic data. Possible departures of genotype frequencies from HWE were estimated by exact tests. Temporal genetic variability among the four sampling years was analyzed with a $\chi^{2}$ contingency test and Wright's F-statistics. Idhp-2 and Pgm were treated as diallelic by pooling the rare alleles with the alternative alleles to avoid problems with low expected frequencies or to eliminate problems of combining $F_{\mathrm{ST}}$ estimates over multiple alleles at a locus (Weir and Cockerham, 1984). Prior to temporal analysis, data were examined for differences between sexes when the sample sizes were sufficient.

Linkage disequilibrium among pairs of polymorphic loci was analyzed separately for each year and for the pooled sample. Again, Idhp-2 and Pgm were treated as diallelic to eliminate the problems with rare alleles. The $\chi^{2}$ statistics was used to test for the nonrandom association between genes. The variance components of linkage disequilibrium were calculated according to Ohta (1982) to identify the disequilibrium patterns. The total variance of the disequilibrium $D_{\text {IT }}^{2}$ was partitioned into within-year $\left(D_{\mathrm{IS}}^{2}, D_{\mathrm{IS}}^{\prime 2}\right)$ and between-year $\left(D_{\mathrm{ST}}^{2}, D_{\mathrm{ST}}^{\prime 2}\right)$ components. This D-statistics can be used to draw conclusions about the proportions of genetic drift and epistatic selection to linkage disequilibrium. The calculations were made with the BIOSYS-1 program of Swofford and Selander (1989) or its modified version BIOSYS-2 (Black WC IV, 1997) with regard to $F_{\mathrm{ST}}$ and linkage disequilibrium analyses.

\section{Results}

Three of the 20 loci were polymorphic at the 0.95 level (Table 1). Gpi had two alleles and Idhp-2 and Pgm three alleles. Furthermore, a single $P g d h^{*} 100 / 225$ heterozygote was observed in the 1999 sample of 32 animals. The correspondence between a particular phenotype and only one genotype was obvious. IDHP and GPI patterns 
Table 1 Allele frequencies for variable loci and heterozygosity based on 20 loci of the wood lemming Myopus schisticolor population in Heinävesi, eastern Finland

\begin{tabular}{|c|c|c|c|c|c|c|}
\hline \multirow[t]{2}{*}{ Locus } & \multirow[t]{2}{*}{ Allele } & \multicolumn{4}{|c|}{ Year (n) } & \multirow[t]{2}{*}{ Mean } \\
\hline & & $1982(27)$ & $1996(28)$ & 1999 (32) & 2002 (97) & \\
\hline \multirow[t]{2}{*}{ Gpi } & -100 & 0.537 & 0.679 & 0.581 & 0.557 & 0.5 \\
\hline & -80 & 0.463 & 0.321 & 0.419 & 0.443 & 0.4 \\
\hline \multirow[t]{3}{*}{ Idhp-2 } & 100 & 0.741 & 0.679 & 0.758 & 0.773 & 0.7 \\
\hline & 50 & 0.259 & 0.321 & 0.242 & 0.222 & 0.2 \\
\hline & 150 & 0 & 0 & 0 & 0.005 & 0.00 \\
\hline \multirow[t]{3}{*}{$P g m$} & 100 & 0.833 & 0.821 & 0.806 & 0.825 & 0.8 \\
\hline & 240 & 0.130 & 0.161 & 0.194 & 0.165 & 0.1 \\
\hline & -65 & 0.037 & 0.018 & 0 & 0.010 & 0.0 \\
\hline \multirow[t]{2}{*}{$P g d h$} & 100 & 1 & 1 & 0.984 & 1 & 0.9 \\
\hline & 225 & 0 & 0 & 0.016 & 0 & 0.0 \\
\hline \multicolumn{7}{|c|}{ Heterozygosity } \\
\hline \multicolumn{2}{|l|}{$H_{\text {obs }}$} & 0.056 & 0.061 & 0.056 & 0.056 & 0.057 \\
\hline \multicolumn{2}{|c|}{$H_{\text {exp }}$} & 0.060 & 0.060 & 0.060 & 0.057 & 0.0 \\
\hline
\end{tabular}

Data are given for four collection years during a 21-year period with their arithmetic means.

Table 2 F-statistics for comparison of genotype frequencies over a 21-year period in wood lemming Myopus schisticolor from Heinävesi, eastern Finland

\begin{tabular}{lrrc}
\hline Locus & \multicolumn{1}{c}{$\mathrm{F}_{I S}$} & \multicolumn{1}{c}{$\mathrm{F}_{I T}$} & $\mathrm{~F}_{S T}$ \\
\hline Gpi & -0.0230 & -0.0143 & 0.0085 \\
Idhp-2 & 0.1041 & 0.1095 & 0.0060 \\
Pgm & -0.0279 & -0.0277 & 0.0003 \\
Mean & 0.0169 & 0.0223 & 0.0056 \\
\hline
\end{tabular}

are also congruent with previous studies on wood lemming (Fedorov, 1990; Fredga et al, 1993; Fedorov et al, 1995). These studies reported PGM and PGDH as being invariant.

Within different sampling years, genotypic proportions conformed to Hardy-Weinberg predictions in each variable locus. This was also true for the 2002 sample subdivided by sex. During the other years too few males were captured to analyze them separately. Among four sampling years, allele frequencies differed most at $\mathrm{Gpi}$ (by 0.14 ) and at $I d h p-2$ (by 0.1), but these differences were not significant $\left(P=0.373\right.$ and 0.534 , respectively). $F_{\mathrm{ST}}$ values varied from 0.0003 to 0.0085 with a mean of 0.0056 (Table 2) and indicated also little genetic differentiation among temporal replicates. When the years were pooled, genotypic proportions were still in HWE and this held also when the data were divided by sex.

Genetic variation among years was not significant (Table 1). The percentage of polymorphic loci was $15 \%$ for all years and the observed heterozygosities varied from 0.056 to 0.061 with a mean of 0.057 . The expected mean heterozygosity was marginally higher (0.059) due to a slight heterozygote deficiency in 1982 and 1999.

The analysis of genotypic associations between pairs of loci in each year indicated three nonrandom associations out of 12 comparisons. Tests for linkage disequilibrium were significant for Idhp-2/Gpi in $1982(P=0.0003)$ and in
$2002(P=0.0482)$ as well as for Gpi/Pgm in 1996 $(P=0.0153)$. Idhp-2/Gpi were also in disequilibrium in the combined data $(P=0.0277)$. Consequently, linkage disequilibrium did not appear consistently in all years as would be expected if selection maintains favorable allelic combinations. Ohta's D-statistics shows that $D_{\text {IS }}^{2}$ is greater than $D_{\mathrm{ST}}^{2}$ indicating that disequilibrium in subsamples is greater than expected by random drift. On the other hand, $D_{\text {IS }}^{\prime 2}$ exceeds $D_{\text {ST }}^{\prime 2}$ indicating that random drift is responsible for the variance in the frequency of allele combinations. According to Ohta (1982), these relations hold for unequal systematic disequilibrium where selection favors for specific allele combinations only in few subsamples.

\section{Discussion}

The two main conclusions of our study are that (1) genetic variation in the Heinävesi population is distinctly higher than has been previously reported in wood lemming and (2) both genetic diversity and population structure remained relatively stable during 21 years corresponding to $40-50$ generations.

The mean expected heterozygosity in Heinävesi was 0.059 , which is somewhat lower than the average 0.067 for 172 mammal species (Ward et al, 1992). In previously studied wood lemming populations the observed mean heterozygosity was 0.034 in western Siberia (Fedorov, 1990,1993 ) and varied from 0.024 to 0.034 in Scandinavia (Fredga et al, 1993). In general, density fluctuations of small mammals reduce effective population size substantially, which is expected to lower genetic diversity and cause inbreeding. However, many microtine populations exhibit rather high genetic variation (Mezhzherin and Serbenyuk, 1992; Filippucci et al, 2002). This is in agreement with both theoretical and empirical observations that the effects of temporary reductions in population size on average heterozygosity may actually be rather small (Nei et al, 1975; Leberg, 1992; Boonstra et al, 1994). The effective population size of the wood lemming is further reduced by skewed sex ratio, but even this did not narrow the genetic variability considerably. The Heinävesi population is unique possessing a considerable amount of variation at Pgm. While this variation is absent from other parts of the distribution area, especially from the possible source area in the east (Fedorov, 1990), Pgm variation may represent an evolutionarily young polymorphism that has arisen in situ. The potential maximum age of the wood lemming population in Heinävesi is around 6000 years. This is the age when spruce forests established in eastern Finland after the last glaciation (Huntley and Birks, 1983). As wood lemming's most preferred habitats are old and mossy spruce-dominated forests, the wood lemming's recolonization into Fennoscandia was undoubtedly connected to the expansion of spruce.

The wood lemming population in Heinävesi is characterized by spatial and temporal dynamics, which are in accordance with the metapopulation concept of Levins (1969). The old spruce forests are patchy and surrounded by waters, fields and younger forests (Eskelinen, 1997). Therefore, wood lemmings are divided into more or less discrete subpopulations. The wood lemming population in Heinävesi also fluctuates regularly in 3 year cycles (Eskelinen, 1997). The local 
populations may go extinct during low population phases and become recolonized again during population peaks. The genetic consequences of such population dynamics are that during the low-phase stochasticity causes subpopulations to differentiate, reduces genetic variation through genetic drift and causes inbreeding depression (Hedrick, 2000). Our analysis of linkage disequilibrium suggested some effects of genetic drift and patchy distribution. These consequences were still rather mild as evidenced by the relatively high and stable heterozygosity and low $F_{\mathrm{ST}}$ among temporal replicates. We argue that well-documented mass movements of wood lemming during its population peaks are causing enough gene flow that balances the differences of subpopulations and keeps the genetic variation relatively stable in the long run. Fredga et al (1993) did not find genetic differences in wood lemming among sampling plots within the same locality. In a more thorough study of spatial genetic differentiation in Siberian lemming, Ehrich and Stenseth (2001) concluded that the populations were rather homogenous within areas stretching over $8 \mathrm{~km}$ or more. This resulted from quite large gene flow between populations caused mainly by males.

In two other studies where temporal variation in wood lemming has been examined, the time span was much shorter. In a Norwegian population the samples from two consecutive years did not differ statistically (Fredga et al, 1993), whereas in a Siberian population allele frequencies were heterogeneous in one of the three variable loci during four successive years (Fedorov, 1993). In other microtine rodents, temporal genetic changes have been documented over periods ranging from 1 to 6 years (Gaines et al, 1978; Baccus and Wolff, 1989; Borkowska, 1999). On the contrary, over a longer time period of 13 years, only minor changes in gene frequencies of red-backed vole were noticed (Mihok et al, 1983). Comparable results were also reported from a moth species, in which allele frequencies varied significantly over 4 years but were relatively stable over 13 years (Raijmann and Menken, 2000). The long-term stability of genetic histories has also been documented in many salmonids (Nielsen et al, 1999; Hansen et al, 2002). Contrasting results have also been presented (Heath et al, 2002; Østergaard et al, 2003), but temporal instability was connected either with human impacts or environmental disturbances. In general, temporal allele frequency shifts seem to be more probable over a small number of generations while stability can be expected over longer time periods.

\section{Acknowledgements}

This work was performed at the Department of Biology, University of Joensuu, which also provided partial funding for lab work. We thank Timo J Hokkanen for his assistance in the collection and handling of the animals in early phases of the study. The paper was benefited from comments by Drew Bodaly, Pekka Pamilo and two anonymous reviewers.

\section{References}

Baccus R, Wolff JO (1989). Genetic composition of fluctuating populations of Peromyscus leucopus and Peromyscus maniculatus. J Mammal 70: 592-602.
Bengtsson BO (1977). Evolution of the sex ratio in the wood lemming, Myopus schisticolor. In: Christiansen FB, Fenchel TM (eds) Measuring Selection in Natural Populations. Lecture Notes in Biomathematics, Vol 19. Springer-Verlag: BerlinHeidelberg, pp 333-343.

Black IV WC (1997). BIOSYS-2. A Computer Program for the Analysis of Allelic Variation in Genetics. Colorado State University: Ft. Collins, CO.

Boonstra R, Hochachka WM, Pavone L (1994). Heterozygosity, aggression, and population fluctuations in meadow voles (Microtus pennsylvanicus). Evolution 48: 1350-1363.

Borkowska A (1999). Genetic and morphological variation among populations of the bank vole Clethrionomys glareolus from north-eastern Poland: the seasonal aspect. Z Säugetierkd 64: 285-297.

Clayton JW, Tretiak DN (1972). Amine-citrate buffers for $\mathrm{pH}$ control in starch gel electrophoresis. J Fish Res Board Canada 29: 1169-1172.

Ehrich D, Stenseth NC (2001). Genetic structure of Siberian lemmings (Lemmus sibiricus) in a continuous habitat: large patches rather than isolation by distance. Heredity 86: 716-730.

Enzyme Nomenclature (1992). Recommendations of the Nomenclature Committee of the International Union of Biochemistry and Molecular Biology on the Nomenclature and Classification of Enzymes. Academic Press: San Diego, CA.

Eskelinen O (1997). On the population fluctuations and structure of the Wood lemming Myopus schisticolor. Z Säugetierkd 62: 293-302.

Eskelinen O (2004). Studies on the ecology of the wood lemming, Myopus schisticolor. PhD Dissertations in Biology, University of Joensuu, Vol 24, pp 1-26.

Fedorov VB (1990). Allozyme polymorphism in a natural population of wood lemmings (Myopus schisticolor Lill.). Genetika 26: 1324-1328 (in Russian with English summary).

Fedorov VB (1991). Microgeographic genetic subdivision and inbreeding level in populations of wood lemming Myopus schisticolor Lill. Soviet Genet 27: 355-360.

Fedorov VB (1993). Genetic variability of wood lemming Myopus schisticolor according to a set of isozyme loci. Russ J Ecol 24: 56-65.

Fedorov VB, Fredriksson R, Fredga K (1995). Genetic differentiation among populations of Myopus schisticolor (the wood lemming) - isozyme variation. Heredity 74: 267-273.

Fedorov V, Jaarola M, Fredga K (1996). Low mitochondrial DNA variation and recent colonization of Scandinavia by the wood lemming Myopus schisticolor. Mol Ecol 5: 577-581.

Filippucci MG, Macholan M, Michaux JR (2002). Genetic variation and evolution in the genus Apodemus (Muridae: Rodentia). Biol J Linn Soc 75: 395-419.

Fredga K, Gropp A, Winking H, Frank F (1976). Fertile XX- and $\mathrm{XY}$-type females in the wood lemming Myopus schisticolor. Nature 261: 225-227.

Fredga K, Fredriksson R, Bondrup-Nielsen S, Ims RA (1993). Sex ratio, chromosomes and isozymes in natural populations of the wood lemming (Myopus schisticolor). In: Stenseth NC, Ims RA (eds) The Biology of Lemmings. Academic Press: London. pp 465-491.

Gaines MS, McClenaghan Jr LR, Rose RK (1978). Temporal patterns of allozymic variation in fluctuating populations of Microtus ochrogaster. Evolution 32: 723-739.

Gileva EA, Fedorov VB (1991). Sex ratio, XY females and absence of inbreeding in a population of the wood lemming, Myopus schisticolor Lilljeborg, 1844. Heredity 66: 351-355.

Hansen MM, Ruzzante DE, Nielsen EE, Bekkevold D, Mensberg KLD (2002). Long-term effective population sizes, temporal stability of genetic composition and potential for local adaptation in anadromous brown trout (Salmo trutta) populations. Mol Ecol 11: 2523-2535.

Heath DD, Busch C, Kelly J, Atagi DY (2002). Temporal change in genetic structure and effective population size in steelhead trout (Oncorhynchus mykiss). Mol Ecol 11: 197-214. 
Hedrick PW (2000). Genetics of Populations, 2nd edn. Jones \& Bartlett, Sudbury, MA.

Herbst EW, Fredga K, Frank F, Winking H, Gropp A (1978). Cytological identification of two X-chromosome types in the wood lemming (Myopus schisticolor). Chromosoma 69: 185-191.

Huntley B, Birks HJB (1983). An Atlas of Past and Present Pollen Maps for Europe: 0-13000 years ago. Cambridge University Press: Cambridge.

Krebs CJ, Myers JH (1974). Population cycles in small mammals. Adv Ecol Res 8: 267-399.

Leberg PL (1992). Effects of population bottlenecks on genetic diversity as measured by allozyme electrophoresis. Evolution 46: 477-494.

Levins R (1969). Some demographic and genetic consequences of environmental heterogeneity for biological control. Bull Entomol Soc Am 15: 237-240.

Liu WS, Eriksson L, Fredga K (1998). XY sex reversal in the wood lemming is associated with deletion of $\mathrm{Xp}(21-23)$ as revealed by chromosome microdissection and fluorescence in situ hybridization. Chromosome Res 6: 379-383.

Maynard Smith J, Stenseth NC (1978). On the evolutionary stability of the female-biased sex ratio in the wood lemming (Myopus schisticolor): the effect of inbreeding. Heredity 41: 205-214.

Mezhzherin SV, Serbenyuk MA (1992). Biochemical variability and genetic divergence of Palearctic arvicolidae - the genus Clethrionomys Tilesius, 1850. Genetika 28: 143-153 (in Russian with English summary).

Mihok S, Fuller WA, Canham RP, McPhee EC (1983). Genetic changes at the transferrin locus in the red-backed vole (Clethrionomys gapperi). Evolution 37: 332-340.

Nei M, Maruyama T, Chakraborty R (1975). The bottleneck effect and genetic variability in populations. Evolution 29: 1-10.

Nielsen EE, Hansen MM, Loeschcke V (1999). Genetic variation in time and space: microsatellite analysis of extinct and extant populations of Atlantic salmon. Evolution 53: 261-268.
Ohta T (1982). Linkage disequilibrium due to random genetic drift in finite subdivided populations. Proc Natl Acad Sci USA 79: 1940-1944.

Østergaard S, Hansen MM, Loeschcke V, Nielsen EE (2003). Long-term temporal changes of genetic composition in brown trout (Salmo trutta L.) populations inhabiting an unstable environment. Mol Ecol 12: 3123-3135.

Raijmann LEL, Menken SBJ (2000). Temporal variation in the genetic structure of host-associated populations of the small ermine moth Yponomeuta padellus (Lepidoptera, Yponomeutidae). Biol J Linn Soc 70: 555-570.

Ridgway GJ, Sherburne SW, Lewis RD (1970). Polymorphism in the esterases of Atlantic herring. Trans Am Fish Soc 99: 147-151.

Shaw CR, Prasad R (1970). Starch gel electrophoresis of enzymes - a compilation of recipes. Biochem Genet 4: 297-320.

Stenseth NC (1978). Is the female biased sex ratio in wood lemming Myopus schisticolor maintained by cyclic inbreeding? Oikos 30: 83-89.

Stenseth NC (1999). Population cycles in voles and lemmings: density dependence and phase dependence in a stochastic world. Oikos 87: 427-461.

Stenseth NC, Ims RA (1993). Population dynamics of lemmings: temporal and spatial variation - an introduction. In: Stenseth NC, Ims RA (eds) The Biology of Lemmings. Academic Press: London. pp 61-96.

Swofford DL, Selander RB (1989). BIOSYS-1: A Computer Program for the Analysis of Allelic Variation in Population Genetics and Biochemical Systematics Release 1.7. University of Illinois, Urbana, Illinois.

Ward RD, Skibinski DOF, Woodwark M (1992). Protein heterozygosity, protein structure, and taxonomic differentiation. In: Hecht MK, Wallace B, MacIntyre RJ (eds) Evolutionary Biology, Vol 26. Plenum Press: New York. pp 73-159.

Weir BS, Cockerham CC (1984). Estimating F-statistics for the analysis of population structure. Evolution 38: 1358-1370. 